\title{
Developing E-module on the Topic of Integrated Addictive Substances with Islamic Values
}

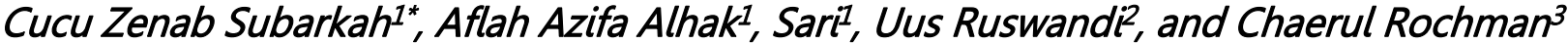 \\ ${ }^{1}$ Department of Chemistry Education, UIN Sunan Gunung Djati Bandung, Indonesia \\ 2 Postgraduate of Islamic Education, UIN Sunan Gunung Djati Bandung, Indonesia \\ ${ }^{3}$ Department of Physics Education, UIN Sunan Gunung Djati Bandung, Indonesia \\ *E-mail: zenabsc@uinsgd.ac.id
}

Received: 24 February 2021 ; Accepted: 16 April 2021 ; Published: 30 June 2021

\begin{abstract}
E-module is one of the media that is considered efficient to be used as a learning media. This research describes the e-module of addictive substances integrated with Islamic values as a solution in preventing and reducing addictive substance abuse, especially among adolescents, by providing scientific knowledge related to religious knowledge. The study aims to analyze the characteristic of e-module and validation results. The emodule is designed with the Design-Based Research (DBR) method with the three steps: analysis, design, and development. Based on the results, the e-module display Islamic views and their interpretation, animated videos, questions, attitude tests, and games. The validation result indicates that the e-module is valid and feasible to be used as a learning media.
\end{abstract}

Keywords: addictive substances topic, e-module, integrated Islamic value

DOI: http://doi.org/10.15575/jtk.v6i1.9802

\section{Introduction}

Chemistry is a science that studies the content, composition, characteristics, and changes of a substance (Perkasa et al., 2018). One of the substances studied in chemistry is addictive substances. Addictive substances can cause dependence, causing health problems that can be seen from changes in attitudes, thoughts, physicality, and moral deviation for users (Government Regulation of the Republic of Indonesia No. 109 of 2012). According to the World Drug Report, users of addictive substances are always increasing every year, especially among students.

One type of addictive substance that can lead to physical and physiological dependence is called narcotics. At the same time, psychotropic is a type of substance that can change mental activity and behavior. Substances classified as addictive substances are alcohol, lozenges, nicotine, and caffeine (Sholihah, 2015). Addictive substances commonly consumed are nicotine in cigarettes, alcohol in liquor, and caffeine in coffee. Unfortunately, many students have started to try and even get addicted to addictive substances in the educational environment, especially among junior high schools (Amanda et al., 2017).

Increased abuse of addictive substances can lead to behavior that deviates from norms (Faridah et al., 2018). This can hamper the goals of national education (Unayah et al., 2016). National education has the aim of creating a nation with good character to be able to advance the nation. Therefore, the purpose of education is not only to impose students on learning outcomes but also to form good character and personality (Zuchdi, 2011). 
Providing knowledge and understanding to students regarding the prohibition of the use of addictive substances associated with knowledge in religion can be done to form students' good character. The approach by providing addictive substance knowledge linked to religious knowledge can prevent curiosity and deviations from the use of addictive substances (Ainiyah, 2013). According to Zain (2017), religious knowledge and science can be integrated because they are interconnected. Al-Qur'an contains scientific concepts and moral values that can be used as learning in character building (Subarkah et al., 2016). One of the phenomena that often occurs in the field is the consumption of alcohol in liquor. The reasons for consuming alcohol are, among others, caused by the environment that is affected by friends. Besides that, they also feel that drinking alcohol can relieve stress and make them feel happy (Tes et al., 2017).

Islam can provide a way to understand science, and science can increase faith (Turgut, 2016). However, for the science to be studied to be intact, it needs to be accompanied by religious principles to improve. Therefore, a rule has been written in the Al-Qur'an as the word of Allah and the Hadith that was conveyed by Rasulullah SAW.

In the Al-Quran Surah Al-Maidah verse 90, there is a prohibition against consuming alcohol. In Surah Al-A'raf verse 31, there is Allah's command to consume something in moderation. A hadith from Muslim History no. 2003 explains that "every khamr is haram and everything that is intoxicating is haram".

According to Nurlila (2017), deviations in addictive substance abuse are caused by decreased psychological and physical conditions making big mistakes. It started from promiscuity that can trigger curiosity to try materials that contain addictive substances and cause addiction. Therefore, it is necessary to provide knowledge that includes addictive substances in teaching materials with a modern appearance.
So far, the teaching materials used in schools are still physical. Students need teaching materials in the form of e-modules as sources of information in learning, especially in the present. Teaching materials contain information in the form of text that has been arranged in a detailed and systematic manner to be used as a learning resource for students (Prawesti et al., 2013). According to Uno (2012), one of the developments in technology is developing printed teaching materials into electronic-based teaching materials called electronic modules (e-modules).

The advantage of e-module is that it can make students easier to understand the material. It is also economical and practical to use as teaching material. E-module can help educators to deliver material and make students not depend on educators to get material explanations. E-module can be used as an independent or group teaching material (Depdiknas, 2008). The use of e-module, which includes addictive substances, aims to produce students with the good character following Islamic teachings.

The importance of this research is to describe the e-module of addictive substances integrated with Islamic values as a solution in preventing and reducing addictive substance abuse, especially among adolescents, by providing scientific knowledge related to religious knowledge. Thus, students can find out the impact of addictive substances and know the law of addictive substances in Islam. In addition, to face education in the $21^{\text {st }}$ century, it is necessary to provide knowledge integrated with Islamic values to students. In the $21^{\text {st }}$ century, national education hopes to produce a creative and productive generation through attitudes, skills, and knowledge integrated with Islamic values (Hanif et al., 2016).

From the explanation above, this research aims to analyze the validation results and describe the appearance of the e-module on the topic of addictive substances integrated with Islamic values. So that the authors are interested in researching with the title "Developing E-module on the Topic of 
Integrated Addictive Substances with Islamic Values".

\section{Research Method}

The method used in this research is DesignBased Research (DBR). Using this method is to develop structured topics to support the learning process by creating innovative learning media to make learning easier for students and improve the quality of education (Herrington, 2007). This research method uses the ADDIE stage development model, which consists of analysis, design, development, implementation, evaluation (Sugihartini et al., 2017).

This research was conducted until the development stage, and the resulting product was an e-module on addictive substances integrated with Islamic values. The stages carried out in this study are as follows:

The analysis stage plays a significant role in the process of making the e-module. First, an analysis of the learning materials and media needed by students is carried out (Astuti et al., 2017). Next, researchers analyzed relevant journals, studied indicators to be achieved in learning, and made concept analyses and concept maps of addictive substances integrated with Islamic values.

The design stage determines goals, creates instruments, and selects media. At this stage, the collection of material, video, animation, pictures, audio related to the material included in the e-module is carried out. Furthermore, the e-module flowchart and storyboard were made (Mapicayanti et al., 2018).

The development stage is carried out by developing a design following the objectives to be achieved in the e-module of addictive substances integrated with Islamic values. After carrying out the analysis and design stages, create an instrument to get results from the appearance and feasibility level of the e-module. So that the initial results will be obtained in the form of an e-module. Finally, the initial product produced will be validated by three competent expert teams: material experts, multimedia experts, and learning media experts (Astuti et al., 2017).

Next, after doing these three stages, make reports on research, data collection, and data analysis. The data collection technique used in this study used a validation questionnaire instrument that was given to three validators, a video on the use of e-module on the topic of addictive substances integrated with Islamic values, which included material aspects and aspects of the e-module display as well as the efficiency of using e-modules as teaching materials.

The data analysis technique was processed based on the instruments used and the data obtained. In this study, the data obtained were in the form of qualitative and quantitative data. First, qualitative data is obtained from instruments in words or images such as flowcharts, storyboards, concept analysis, concept maps, and suggestions from the validator (Boisandi, 2019). Meanwhile, quantitative data is obtained by calculating statistics based on the validation results on a Likert scale (Arikunto, 2013).

\section{Result and Discussion}

Making e-modules uses the Lectora Espire application, an application used as a presentation or learning media. The advantages of the Lectora application can be used as a learning medium both offline and online (Handoyono et al., 2020). During the Covid-19 pandemic, applications that support online learning (E-Learning) are urgently needed because the teaching and learning process is carried out online at home (Aji et al., 2020). E-learning is a learning development that can be used in delivering material and increasing students' competence (Bele et al., 2018). E-learning requires pedagogical knowledge to create an optimal learning process (Gunawan, 2014). Pedagogic competence is the ability of educators to carry out their duties as educators based on prevailing demands. Good pedagogical competence will teach cultural values that will 
influence attitudes that impact student learning outcomes (Kurniawati, 2020).

In the $21^{\text {st }}$ century, educators are challenged to have skills in technology, namely electronicbased learning media (Bele et al., 2018). One of the technology-based learning media is the e-module. E-module can make it easy for students to understand the material and think highly by solving problems. The e-module contains material in videos, pictures, animation, audio, evaluation tests and feedback from learning (Wati et al., 2016). The e-module display on addictive substances integrated with Islamic values also contains images, videos, audio, evaluation questions, and feedback. Following are the results and discussion obtained in this research:

\subsection{Description of E-module Display on the Topic of Integrated Addictive Substances Islamic Values}

This e-module was made as a teaching material for class VIII science subjects for additives and addictives, which refers to Basic Competencies; 1 ) Describing additives (natural and artificial) in food and beverages (fresh and in packs), and addictive-psychotropic substances and their effects on health. 2) Describing the relationship between the properties of materials and their use in everyday life and the influence of certain materials on human health.

The topics listed in the e-module cover groups of other addictive substances, including alcohol, nicotine and caffeine, which are integrated with Islamic values. The topic of addictive substances integrated with Islamic values is obtained from material analysis and interpretations of the Al-Qur'an and Hadiths that support the moral message. In life, always does good without deviating into the wrong path, especially in the abuse of addictive substances. In addition, students are expected to know the power, the truth of God Almighty and the relationship between science and the Al-Qur'an and Hadiths that can increase faith as evidenced by noble, knowledgeable, and responsible morals (Rahmah, 2017).
The e-module display follows the flowchart and storyboard that has been made. The flowchart describes the use and chart of the material to be discussed in the e-module. The storyboard describes the pictures, videos, materials, and evaluation questions according to the indicators to be achieved. For example, the following is an e-module display on the topic of addictive substances integrated with Islamic values that the three validators have validated:

\subsubsection{E-module Front View}

On the cover, there is an identity that is contained in the e-module (Kurniawati, 2020). In addition, there is an e-module title for the topic of addictive substances integrated with Islamic values accompanied by a "Go" button that indicates to start learning on the next page. The cover display e-module can be seen in Figure 1.

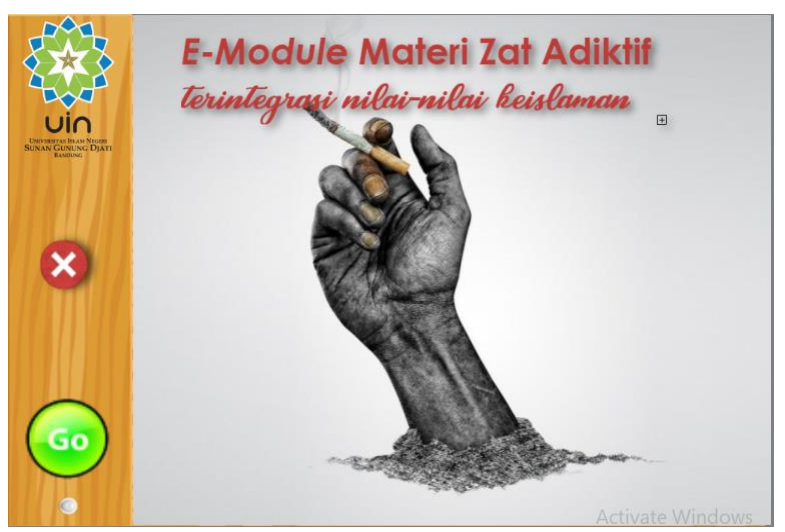

Figure 1. E-module Cover

\subsubsection{Table of Contents of the E-module}

According to Purnama (2011), the main page shows the menu contained in the e-module that can link to the page to be addressed, includes instructions for using the e-module, learning objectives for the topic of addictive substances integrated with Islamic values, the topic of addictive substances including various addictive substances, the impact of using addictive substances, good attitudes in consuming something according to Islam, factors that cause substance use addictive, efforts to prevent the use of addictive substances, and profiles of e-module makers. The display of the table of contents of the emodule can be seen in Figure 2. 


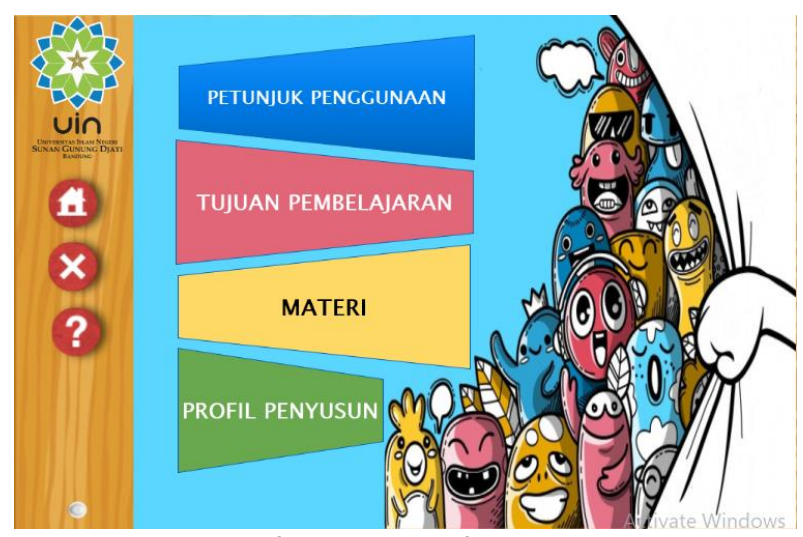

Figure 2. Table of Contents of the E-module

\subsubsection{Instructions for Use}

Instructions for use make it easier for readers to find it difficult or confused to run the emodule program (Wijaya et al., 2018). So that information is provided for the buttons used in the e-module. For example, the display of emodule usage can be seen in Figure 3.

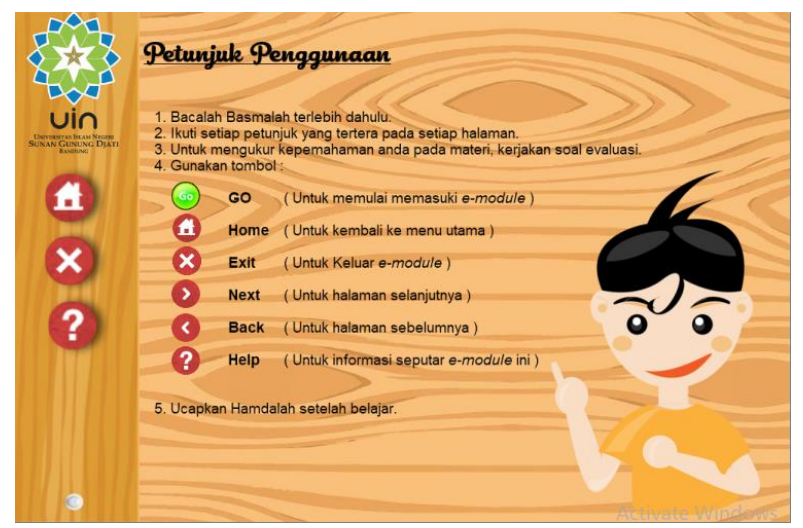

Figure 3. Instructions for Using the E-module

\subsubsection{Knowledge Evaluation Questions}

There are five knowledge questions to measure students' understanding of mastering learning material (Kurniawati, 2020). After students or readers have answered all the questions, they will be given feedback in the form of the scores obtained according to the answers that have been done and there will be corrections to the answers if there are wrong answers when working on the questions. The e-module feedback display can be seen in Figure 4.

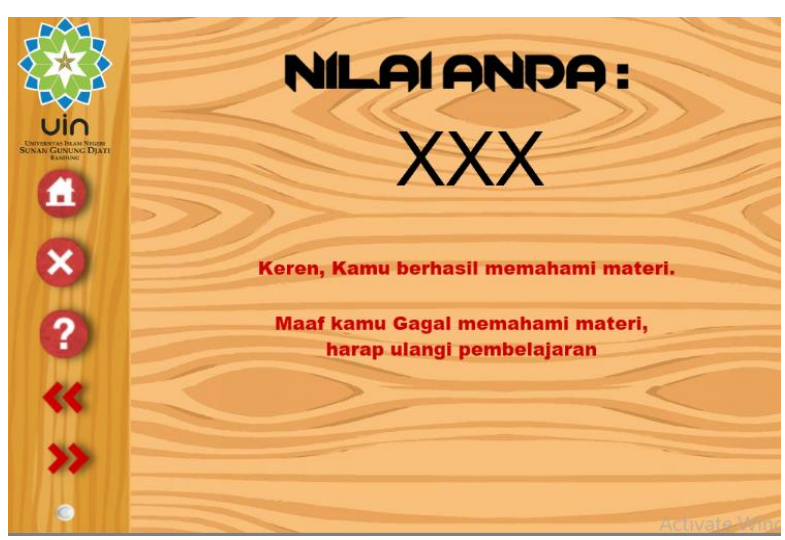

Figure 4. Learning Evaluation Questions Feedback

\subsubsection{Attitude Test}

The attitude test aims to determine the reader's concern for the environment (Rahmah, 2017). In this study, prioritized care in dealing with the prevention of addictive substance abuse. The display of the e-module attitude test can be seen in Figure 5 .

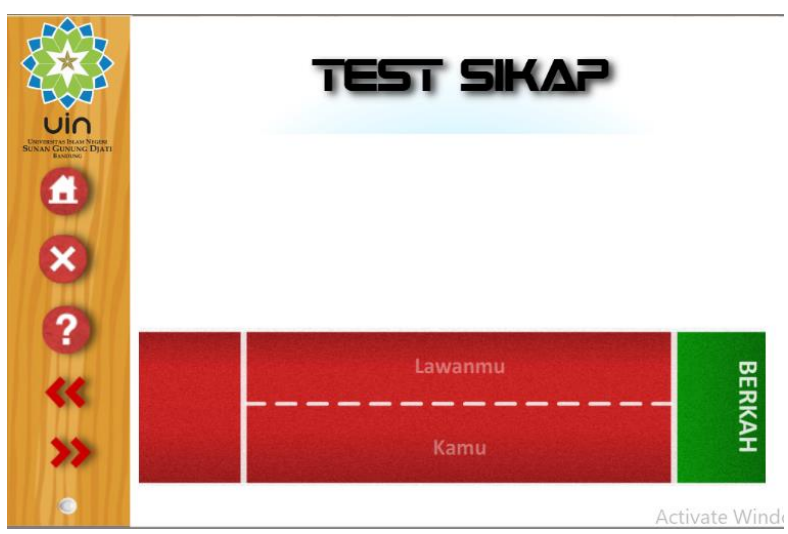

Figure 5. Attitude Test

\subsubsection{Cognitive Peak Game}

The cognitive peak game contains five knowledge questions with easy question categories to provide interesting learning for students and improve understanding of addictive substances (Ditama et al., 2015). If the student succeeds in answering the questions, they successfully climb the mountain. Conversely, if you answer the question wrongly, you will jump or fail to climb. At the end of the game, the score obtained from the answer to the question that has been worked will be displayed in Figure 6 . 


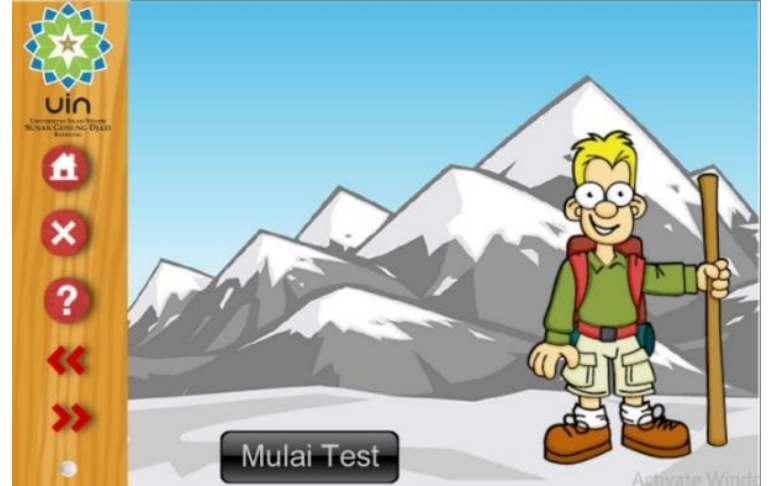

Figure 6. Cognitive Test

The display of the e-module material that has been corrected according to the validator's suggestions is as follows:

Figure 7 shows a verse from the Al-Quran regarding the Islamic view of consuming something excessively contained in caffeine material. The Surah quoted is Al-A'raf verse 31, which is equipped with a translation and interpretation.

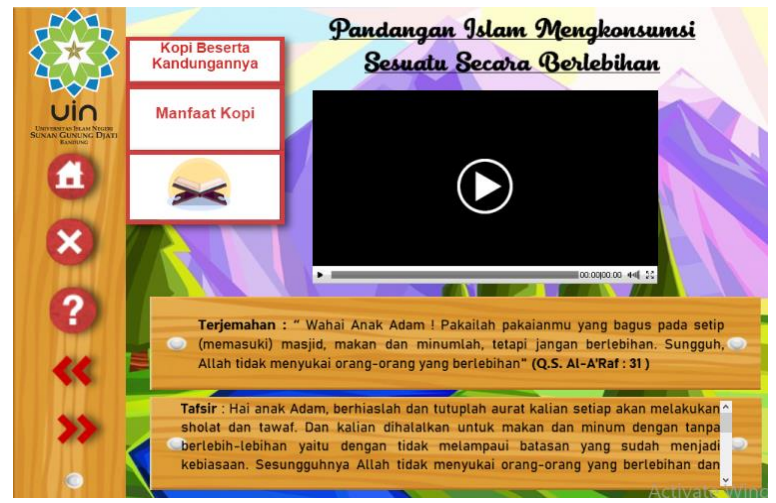

Figure 7. Display of E-module Content

Furthermore, alcohol is equipped with the ethanol structure, videos of the use of liquor in the community, and the classification of liquor based on its alcohol content. According to the minister of health regulation, the classification of liquor is divided into three groups: A, B, and C. A display of e-module content is shown in Figure 8.

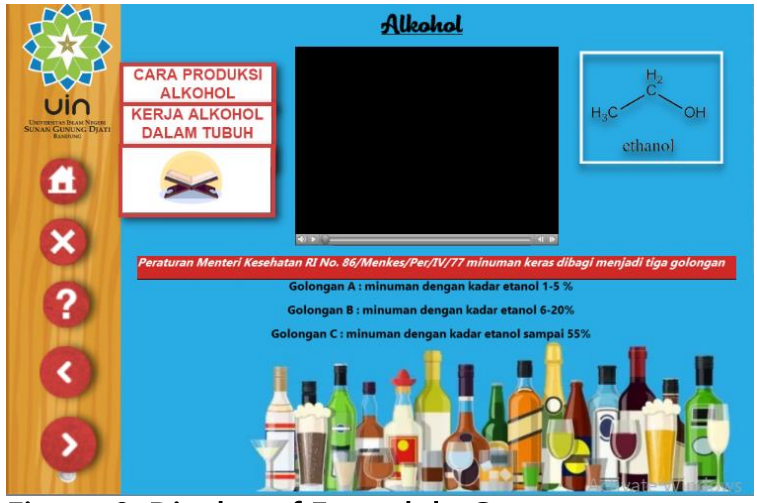

Figure 8. Display of E-module Content

The material contained in the e-module is displayed in the form of text, video, audio, animation, and images that can make it easier for students to understand learning material (Zulvianda et al., 2013). Figure 9 shows an example of the text material contained in the e-module:

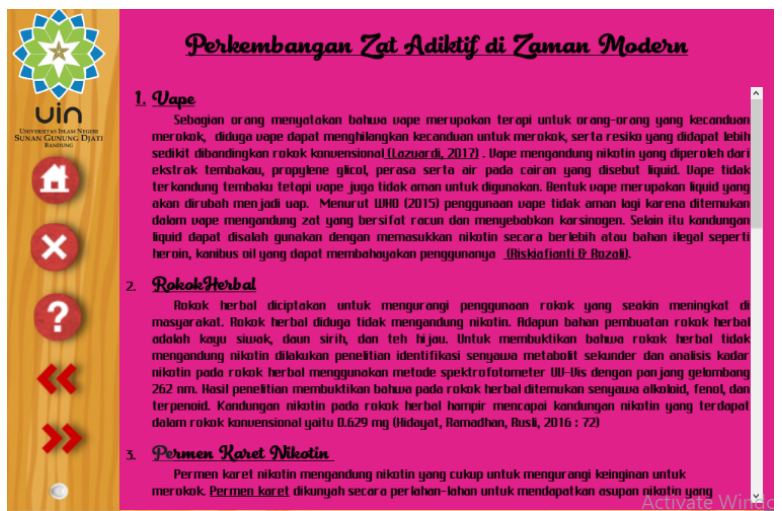

Figure 9. Display of a Brief Description of the Emodule Material

Figure 9 describes the material development of addictive substances in modern times, including the functions, ingredients and dangers of e-cigarettes, herbal cigarettes, and nicotine gum.

\subsection{Analyzing E-module Validation Test Results on the Topic of Addictive Substances Integrated with Islamic Values}

Validation was carried out by three validators consisting of material experts, media experts, and multimedia experts. Material experts provide input on material already contained in the e-module, multimedia experts provide suggestions on the appearance and how to use the e-module, and learning media experts 
provide input on the ease and efficiency of using e-modules in learning.

The results of the validator respondent questionnaire indicate the feasibility $(r)$ of each assessment criterion used in the emodule formation stage. The value $(r)$ is compared with the critical $r$-value, which is $r=$ 0.3 . If the value of each criterion is more than 0.3 , then the criterion item is declared valid (Sugiyono, 2017). The formula used for the feasibility value $(r)$ is based on the theory presented by Sugiyono.

Table 1 show the validation result

Table 1. Data Processing Validation Results

\begin{tabular}{lll}
\hline Presentation Aspects & $\mathrm{r}_{\text {count }}$ & $\mathrm{r}_{\text {critical }}$ \\
\hline Material Aspects & 0.866 & 0.3 \\
E-Module Display Aspects & 0.845 & 0.3 \\
\hline Average & 0.855 & 0.3
\end{tabular}

From these data, it was obtained an average value of 0.855 . This shows that the e-module on addictive substances integrated with Islamic values is valid and has a high interpretation of feasibility to be used as a learning medium, following the interpretation of the feasibility value based on the r-value.

\section{Conclusion}

Based on the results of research on making emodules on the topic of addictive substance integrated with Islamic values, it is found that the e-module display includes the topic of addictive substances, which is equipped with Islamic views in the form of verses of the Qur'an and its interpretation, animated videos regarding the impact of the use of addictive substances, factors causes of addictive substance use, efforts to prevent addictive substance abuse, evaluation questions, attitude tests, and games. The validation results of the three validators are 0.855 , which indicates that the e-module on the topic of addictive substances, which is integrated with Islamic values, can be used as a learning medium because it is declared valid and has the high interpretation of its feasibility to be used as a learning medium.

\section{References}

Ainiyah, N. (2013). Pembentukan karakter melalui pendidikan agama Islam. Jurnal Al Ulum,13(1), 25-38. Retrieved from http://www.journal.iaingorontalo.ac.id/in dex.php/au/article/view/179

Aji, W., Dewi, F., Kristen, U., \& Wacana, S. (2020). Dampak Covid-19 terhadap implementasi pembelajaran daring di sekolah dasar [COVID-19 impact on the implementation of online learning in primary schools]. Edukatif. Jurnal Ilmu Pendidikan, 2(1), 55-61. https://doi.org/10.31004/edukatif.v2i1.8 9

Amanda, M., Humaedi, S., \& Santoso, M. (2017). Penyalahgunaan narkoba di kalangan remaja (adolescent substance abuse). Journal UNPAD, 4(2), 339-345. https://doi.org/10.24198/jppm.v4i2.1439 2

Arikunto. (2013). Prosedur penelitian: Suatu pendekatan praktik. Jakarta: PT Rineka Cipta.

Astuti, I. A., Sumarni, R. A., \& Saraswati, D. L. (2017). Pengembangan media pembelajaran fisika mobile learning berbasis android. Jurnal Penelitian \& Pengembangan Pendidikan Fisika, 3(1), 57-62. https://doi.org/10.21009/1.03108

Bele, F., \& Made, D. (2018). Inovasi pembelajaran elektronik dan tantangan guru abad 21. Journal Penelitian dan Pengkajian Ilmu Pendidikan 2(1), 10-18. https://doi.org/10.36312/esaintika.v2i1.79

Boisandi. (2019). Pengembangan modul analisis rangkaian listrik berbasis inkuiri. Prosiding Seminar Nasional Pendidikan MIPA dan Teknologi, 1(1) 245. Retrieved from

https://journal.ikippgriptk.ac.id/index.ph p/snpmt2/article/view/1380 
Departemen Pendidikan Nasional (Depdiknas) (2008). Panduan pengembangan bahan ajar. Jakarta: Depdiknas

Ditama, V., Saputro, S., \& S, A. N. C. (2015). Pengembangan multimedia interaktif dengan menggunakan program adobe flash untuk pembelajaran kimia materi hidrolisis garam SMA kelas XI. Jurnal Pendidikan Kimia, 4(2), 23-31. Retrieved from

https://jurnal.fkip.uns.ac.id/index.php/ki mia/article/view/5669

Faridah, F., \& Atakari, E. R. (2018). Hubungan pola asuh orang tua dengan penggunaan narkotika, psikotropika dan zat adiktif lainnya (napza) pada remaja. Jurnal Kebidanan, 8(2), 138-142.

Gunawan, I. (2014). Pedagogi dan teknologi dalam e-learning. Jurnal Ilmiah Pendidikan Fisika Al-Biruni, 3(2), 16-23. https://doi.org/10.24042/jpifalbiruni.v3i2 .70

Handoyono, N., Suparmin, \& Nugroho, H. (2020). Pengembangan e-modul berbasis lectora pada pembelajaran sistem REM. Jurnal Pendidikan Teknologi dan Kejuruan, 17(2), 156-165. http://dx.doi.org/10.23887/jptkundiksha.v17i2.24380

Hanif, H., Ibrohim, I., \& Rohman, F. (2016). Pengembangan perangkat pembelajaran biologi materi plantae berbasis inkuiri terbimbing terintegrasi nilai islam untuk meningkatkan pemahaman konsep siswa SMA. Jurnal Pendidikan: Teori, Penelitian, dan Pengembangan, 1(11), 2163-2171. http://dx.doi.org/10.17977/jp.v1i11.8042

Herrington, J., et al. (2007). Design based research and doctoral students: guidelines for preparing adissertation proposal. Proceedings of World Conferenceon Educational Multimedia, Hypermedia and Telecommunications, 4089-4097. Retrieved from https://www.learntechlib.org/p/25967/
Kurniawati, E. F. (2020). Pengimplementasian e-modul etnokonstruktivisme terhadap motivasi belajar peserta didik kelas $\mathrm{V}$ sekolah dasar. Jurnal Penelitian Ilmu Pendidikan, 13(1), 10-21. https://doi.org/10.21831/jpipfip.v13i1.26 589

Mapicayanti, D., Jamaludin, \& Fathoni, A. (2018). Perancangan media pembelajaran berbasis video tutorial mendesai jaringan lokal/LAN kelas X TKJ. Jurnal Pendidikan Informatika, 2(2), 59-65. Retrieved from https://e-

journal.hamzanwadi.ac.id/index.php/edu matic/article/view/913

Nurlila, R. U., \& La Fua, J. (2017). Penyalahgunaan zat adiktif pada siswa kelas viii di sekolah menengah pertama negeri 05 kota Kendari. Jurnal Al-Ta'dib, 10(1), 73-90. https://doi.org/10.31332/ATDB.V10I1.55 3

Resyta, A., Melati, H. M.,\& Hadi, L. M. (2015) Pengembangan media chembo (chemistry board) materi zat adiktif dan psikotropika siswa kelas VIII SMP. Jurnal Pendidikan dan Pembelajaran Katulistiwa. Retrieved from https://jurnal.untan.ac.id/index.php/jpdp b/article/view/11306

Perkasa, M., Annafi, N., \& Putri, M. (2018). Penerapan pembelajaran kimia berbasis lingkungan melalui model project based learning untuk meningkatkan sikap peduli lingkungan mahasiswa. Prosiding Seminar Nasional, 296-300. https://doi.org/10.31219/osf.io/z6eju

Prawesti, R. A., Lutfi, A., \& Suprapro, N. (2013). Uji coba pembelajaran IPA terpadu dengan LKS berorientasi guided discovery untuk melatih keterampilan berpikir ilmiah pada tema es lilin. PENSA: E-Jurnal Pendidikan Sains, 1(2), 35-41. Retrieved from https://ejournal.unesa.ac.id/index.php/p ensa/article/view/2217 
Purnama, B. E., Yuniati, N., \& Nugroho, G. K. (2011). Pembuatan media pembelajaran interaktif ilmu pengetahuan alam pada sekolah dasar negeri kroyo 1 sragen. 3(4), 25-29. Retrieved from http://lppm.upiyptk.ac.id/ojsupi/index.p $\mathrm{hp} / \mathrm{pti} /$ article/view/130

Rahmah, S. Z. (2017). Pengembangan modul berbasis SETS (science, environment, technology, society) terintegrasi nilai islam di smai surabaya pada materi lkatan Kimia. Jurnal Pendidikan, 2, 57-62. http://dx.doi.org/10.26740/jp.v2n1.p7076

Sholihah, Q. (2015). Efektivitas program P4Gn terhadap pencegahan penyalahgunaan napza. Jurnal Kesehatan Masyarakat, 10(2), 153. https://doi.org/10.15294/kemas.v10i2.33 76

Subarkah, C. Z., Rahmawati, R., \& Dalli, A. (2016). Value in electrochemistry learning. Jurnal Pendidikan Islam The Faculty of Tarbiyah and Teacher Training State Islamic University (UIN) Sunan Gunung Djati Bandung, 2. Retrieved from https://www.researchgate.net/profile/Fer li-Septi-

Irwansyah/publication/327770698_Devel oping_E-

Module_Based_on_Islamic_Values/links/5 bc35582a6fdcc2c91fbe302/DevelopingE-Module-Based-on-Islamic-Values.pdf

Sugihartini, N., Jayanta, N. L. (2017). Pengembangan e-module mata kuliah startegi pembelajaran. Pendidikan Teknologi dan Kejuruan, 14(2), 221-230. http://dx.doi.org/10.23887/jptkundiksha.v14i2.11830

Sugiyono. (2017). Metode penelitian pendidikan (pendekatan kuantitatif, kualitatif, dan R\&D). Bandung: Alfabeta.

Tes, A. A., Puspitawati, T., \& Marlinawati, U. (2017). Fenomena perilaku mengkonsumsi minuman keras mahasiswa program studi s-1 kesehatan masyarakat Universitas Respati Yogyakarta. Jurnal Formil (Forum Ilmiah) Kesmas Respati, 2(1), 27-28. https://doi.org/10.35842/formil.v2i1.59

Turgut, H. (2016). Pre-service science teachers' perceptions about relationship between religion and science on the context of their worldviews. International Online Journal of Educational Sciences, 8(3), 2016.

https://doi.org/10.15345/iojes.2016.03.0 14

Unayah, N., \& Sabarisman, M. (2016). Fenomena kenakalan remaja dan kriminalitas. Sosio Informa, 1(2).

Uno, H. B. (2012). Model pembelajaran. Jakarta: Bumi Aksara.

Wati, H. P., Karyanto, P., Dwiastuti, S. R. I., \& Sri, D. (2016). Upaya meningkatkan keterampilan proses sains dan mengurangi miskonsepsi melalui penerapan e-module berbasis problembased learning kelas X MI 2 SMA Batik 1 Surakarta. Bio-Pedagogi, 5(4). https://doi.org/10.20961/biopedagogi.v5i1.5402

Wijaya, I., \& Firmansyah, D. (2018). Perancangan dan pembuatan media pembelajaran berbasis android mata pelajaran teknologi perkantoran (studi kasus kelas X OTP SMK Negeri 3 Padang). Pendidikan Teknologi Informasi, 5(2), 920. Retrieved from http://lppm.upiyptk.ac.id/ojsupi/index.p hp/pti/article/view/130

Zain, Z., \& Vebrianto, R. (2017). Integrasi keilmuan sains dan Islam dalam proses pembelajaran rumpun IPA. Jurnal Program Studi Pendidikan Kimia, 18-19. Retrieved from http://ejournal.uinsuska.ac.id/index.php/SNTIKI/article/vie w/3198 
Zuchdi, D. (2011). Pendidikan karakter dalam perspektif teori dan praktik. Yogyakarta: UNY Press.

Zulvianda, H., Hanum, L., \& Nazar, M. (2013). Pengembangan e-module kimia SMA pada materi larutan elektrolit dan non elektrolit. Jurnal Ilmiah Mahasiswa Pendidikan Kimia (JIMPK), 1(3), 9-16. Retrieved from http://www.jim.unsyiah.ac.id/pendidikan -kimia/article/view/1295 